\title{
Land and politics in independent Ireland, 1923-48: the case for reappraisal
}

$\mathrm{T}$ he land question from the mid-Victorian period to around 1903 looms large in Irish historiography. This is hardly surprising given the fact that, while it was immensely important in its own right, it could not be disentangled from the wider political developments of the time that saw the land and national questions merge. ${ }^{1}$ However, with the exception of recent work by Professor David Seth Jones, the land question in post-independence Ireland has been largely overlooked. ${ }^{2}$ There seems, in fact, to be a general assumption among political, social and economic historians that there was no land question after 1922, that the land act of the following year defused all potential for future agrarian unrest by completing the transfer of ownership from landlords to tenants. ${ }^{3}$ Nowhere is this hypothesis more clearly pronounced than in J. J. Lee's Ireland 1912-1985: politics and society (1989), in which the author contends that at independence

There was no longer a viable landlord system. Most Irish farmers became the effective owners of their holdings before 1921. The 1923 Land Act permitted the remaining tenants to purchase their holdings quickly, but the major changes in land ownership occurred before independence, contrary to frequent eastern European experience. The government

\footnotetext{
${ }^{1}$ Major works in which the land question plays the dominant role include Paul Bew, Land and the national question in Ireland, 1858-82 (Dublin, 1978); Philip Bull, Land, politics and nationalism: a study of the Irish land question (Dublin, 1996); Samuel Clark, Social origins of the Irish land war (Princeton, 1979); J. S. Donnelly, jr, The land and the people of nineteenth-century Cork: the rural economy and the land question (London, 1975); Laurence Geary, The Plan of Campaign, 1886-91 (Cork, 1985); David Seth Jones, Graziers, land reform and political conflict in Ireland (Washington, D.C., 1995); D. E. Jordan, Land and popular politics in Ireland: County Mayo from the plantation to the land war (Cambridge, 1994); T. W. Moody, Davitt and Irish revolution, 1846-82 (Oxford, 1981); B. L. Solow, The land question and the Irish economy, 1870-1903 (Cambridge, Mass., 1971); W. E. Vaughan, Landlords and tenants in mid-Victorian Ireland (Oxford, 1994).

${ }^{2}$ David Seth Jones, 'Divisions within the Irish government over land distribution policy, 1940-70' in Éire-Ireland, xxxvi (2001), pp 83-109.

${ }^{3}$ See, for example, F. S. L. Lyons, Ireland since the Famine (London, 1971), p. 606; John A. Murphy, Ireland in the twentieth century (Dublin, 1975), p. 65; Ronan Fanning, Independent Ireland (Dublin, 1983), p. 73; J. J. Lee, Ireland 1912-1985: politics and society (Cambridge, 1989), p. 71; Alvin Jackson, Ireland 1798-1998: politics and war (Oxford, 1999), p. 283; David Fitzpatrick, The two Irelands, 1912-1939 (Oxford, 1998), p. 240. See also R. F. Foster, Modern Ireland, 1600-1972 (London, 1988); Dermot Keogh, Twentieth-century Ireland: nation and state (Dublin, 1994); Cormac Ó Gráda, Ireland: a new economic history, 1780-1939 (Oxford, 1994); idem, A rocky road: the Irish economy since the 1920s (Manchester, 1997); Charles Townshend, Ireland: the twentieth-century (London, 1999); Mike Cronin and J. M. Regan (eds), Ireland: the politics of independence, 1922-49 (Basingstoke, 2000).
} 
was not therefore exposed to the temptation to manipulate land reform extensively for political purposes, which might have spawned massive corruption and provoked widespread grievance. Such limited land re-distribution as occurred continued to be channelled through the safer conduits of the Land Commission. Communities were not generally rent asunder by rival claims to land. ${ }^{4}$

The primary aim of this article is to suggest that such traditional assumptions are fundamentally flawed. By focusing upon the administrative periods of Cumann na nGaedheal (1923-32) and Fianna Fáil (1932-48), it argues the case that there is a need to reassess the centrality of the land question to both national and local politics after independence.

This article also suggests that it is important to reassess the significance of the Land Commission after 1923 to Irish rural life. Needless to say, such a reassessment would be greatly facilitated by the opening of the Irish Land Commission records to the public. In fact more open access to these records (estimated to run to around 11 million in total) would greatly enhance primary research into all aspects of the social, economic, cultural and, indeed, political history of Ireland since the establishment of the commission under the terms of the 1881 land act. (These records include title-deeds some of which date back to at least the fifteenth century, maps and related papers, records of Land Commission proceedings, correspondence, inspectors' reports on individual holdings and families, as well as the records generated by the Ecclesiastical Commissioners who conducted the disposal of church lands after disestablishment in 1869 and the records of the Congested Districts Board set up under the 1891 land act and disbanded in 1923 which elucidate the social, economic and cultural circumstances of people living along the western seaboard.) At present there remains a difficulty in accessing these records, as they are still deemed to be "working records'5 and, therefore, covered by section 8 (2) of the 1986 National Archives Act that effectively excludes from the terms of the act records over thirty years old that continue to be working records or which contain information that might cause 'distress or danger to living persons on the grounds that they contain information about individuals, or would or might be likely to lead to damages for defamation' ${ }^{6}$

However, as this article is primarily concerned with land division and what can perhaps be best described as the lost politics of independent Ireland, it should be emphasised that access to the Land Commission records was not deemed essential to its completion. While the Land Commission records are a veritable goldmine in their own right, their inaccessibility should not be regarded as precluding research on the whole issue of the land question after 1922. Fortunately, there is a rich vein of other records presently in the public domain that, for the purposes of the present study, is more than ample compensation.

${ }^{4}$ Lee, Ireland 1912-1985, p. 71.

${ }^{5}$ Text of parliamentary question no. 84, ref. 4180/03, and reply from Minister for Agriculture, 13 Feb. 2003, forwarded to the present author by Ms Deirdre Fennell, private secretary to John Bruton, T.D.

${ }^{6}$ An act to provide for the establishment of a body to be known as the National Archives and for other connected matters (11/1986) (18 May 1986). 
In July 1922 a government spokesman wrote that 'The completion of the land acts is the most earnest concern of the Government of Ireland. As soon as internal affairs are sufficiently stable to warrant a step forward, measures will be taken to settle finally the land question." However, by January 1923, after six further months of civil war, it was recognised within government circles that, in fact, the final settlement of the land question through legislation could possibly be a major step towards the restoration of law and order. ${ }^{8}$ Given the historical precedents since the 1880 s of defusing agrarianism with land legislation, this response was perhaps predictable in light of the dramatic growth in agrarian crime during 1922 that was, rightly or wrongly, predominantly associated in the popular perception with the activities of the anti-treaty faction, who were accused of rallying support in the localities by exploiting traditionally emotive agrarian grievances. This was particularly true of the west, from where Colonel Maurice Moore wrote a revealing letter to the Minister for Defence in May 1922:

The anti-Treaty politicians and I.R.A. finding themselves in a hopeless minority, have adopted a policy very dangerous to the country and to the present ministry, though it has not been openly avowed. They are now making a bid for support through an agrarian movement. ${ }^{9}$

The following December, Patrick Hogan, the influential Minister for Agriculture, told his parliamentary colleagues that he felt the anti-treatyites were attempting to make up lost ground by becoming involved in widespread landgrabbing: 'It would have the advantage of being much more popular, in fact quite in the best traditions. The "land for the people" is almost as respectable an objective as the "republic" and would make a much wider appeal., 10

Hogan had his finger very firmly on the rural pulse. While land and political issues had traditionally been inextricably entwined in Ireland, it was arguably land issues that had provided the momentum to political movements rather than vice versa. For the majority of people living in rural Ireland, access to land continued to be a possibly more desirable commodity than independence, and the Anglo-Irish treaty of 1921 had made no provision for the completion of land purchase or the redistribution of large untenanted estates. Since 1917 agrarianism had arguably been fuelled by revolutionary activity; but it was by no means dependent upon it. Rural social conditions remained such that another phase of agrarianism was probably imminent even if a home rule parliament had been put in place. The unwillingness of some landlords to sell their tenanted estates and then the suspension of land purchase during the First World War meant that there remained 114,000 unpurchased tenants. Of perhaps more concern were the 295,566 uneconomic occupiers of one to thirty acres (plus a further 112,787 occupiers of less than one acre) who looked jealously upon the 33,400 holdings of over 100 acres. These large holdings comprised in total around 7.3 million

\footnotetext{
${ }^{7}$ J. M. Duff to - McGann, 18 July 1922 (N.A.I., DT S2981).

${ }^{8}$ Dáil Éireann deb., ii, 592 (5 Jan. 1923).

${ }^{9}$ Maurice Moore to the Minister for Defence, 9 May 1922 (Military Archives, Dublin (henceforth M.A.), A/3126).

${ }^{10}$ [Patrick Hogan], 'Seizures of land' (copy memo), 22 Dec. 1922 (N.A.I., DT S1943).
} 
acres, approximately one-third of the country's total acreage and well above that proportion in terms of its arable acreage. ${ }^{11}$

The findings of the land purchase sub-committee of the Irish Convention of 1917 and the subsequent drafting of the 1920 land bill with its compulsory acquisition terms, even if they were limited, were strongly suggestive of the perceived need to settle the Irish land question once and for all. ${ }^{12}$ But both the convention and the land bill were doomed to failure. From 1917 grievances gave rise to an increase in agrarian crime that flourished in the conditions created for it by the Anglo-Irish conflict. ${ }^{13}$ From 1920 land-grabbing became a major and worrying feature of rural society; thousands of unpurchased tenants struck against the payment of rents, while even purchased tenants availed of the opportunity not to pay their Land Commission annuities, most taking advantage of the social chaos that made it virtually impossible to collect rents or resort to the courts for their enforced payment. ${ }^{14}$ In April 1923 landlord representatives went so far as to claim that only on about 10-15 per cent of tenanted estates had rents been paid up to date. ${ }^{15}$ Thus the involvement of the anti-treatyites in agrarianism from 1922, that so perturbed first the Provisional and then the Free State governments, merely exacerbated an existing situation.

From December 1922 the Free State government adopted a number of approaches to deal with agrarian disorder. In that month Hogan proposed that the army should take 'immediate and drastic action against people who [had] seized other people's land'. In February 1923 the Minister for Defence, acting on Hogan's suggestion, established a Special Infantry Corps specifically to tackle agrarian disorder. ${ }^{16}$ There was strong opinion within government circles that force alone was not going to be enough (there was always the likelihood that sustained activity by the Special Infantry Corps would aggravate unrest. ${ }^{17}$ Thus in March 1923 the Free State government took its first legislative steps towards

\footnotetext{
${ }^{11}$ Agricultural statistics of Ireland with detailed report for the year 1917 [Cmd 1316], H.C. 1921 , xli, p. xiv.

${ }^{12}$ Report of the proceedings of the Irish Convention [Cd 9019], H.C. 1918, x. 697; memorandum on land bill of 1920 , n.d. (N.A.I., DT S1995A).

${ }^{13}$ Historians remain at variance regarding the nature, role and extent of agrarianism during the Irish War of Independence and the Civil War. For various opinions see Paul Bew, 'Sinn Féin, agrarian radicalism and the War of Independence' in D. G. Boyce (ed.), The revolution in Ireland, 1879-1923 (Dublin, 1988), pp 217-35; Charles Townshend, Political violence in Ireland: government and resistance since 1848 (Oxford, 1983); Joost Augusteijn, From public defiance to guerrilla warfare: the experience of ordinary volunteers in the Irish War of Independence, 1916-2l (Dublin, 1996); J. M. Regan, The Irish counter-revolution, 1921-36 (Dublin, 1999); Peter Hart, 'Definition: defining the Irish revolution' in Joost Augusteijn (ed.), The Irish revolution, 1913-1923 (Basingstoke, 2002), pp 17-33; Terence Dooley, 'I.R.A. veterans and land division in independent Ireland, 1923-48' in Fearghal McGarry (ed.), Republicanism in modern Ireland (Dublin, 2003), pp 86-107.

${ }^{14}$ Memorandum by Patrick Hogan on land bill of 1920 (N.A.I., DT S1995); Dáil Éireann deb., iv, 1983-4 (8 Aug. 1923).

${ }^{15}$ Patrick Hogan to W. T. Cosgrave, 7 Apr. 1923 (N.A.I., DT S3192).

${ }^{16}$ [Patrick Hogan], 'Seizures of land' (copy memo), 22 Dec. 1922 (N.A.I., DT S1943); Department of Defence memorandum, 1 Feb. 1923 (M.A., A/7869).

${ }_{17}$ See, for example, M.A., files A/8506, A/7869, A/613, detailing activities of the Special Infantry Corps, resistance to the same in certain areas, its success in quelling agrarianism, and so on.
} 
the restoration of rural law and order with the enactment of the Enforcement of Law (Occasional Powers) Act and the District Justices (Temporary Provisions) Act. ${ }^{18}$

The Enforcement of Law Act was passed to undo the paralysis that had adversely affected the executive machinery of the courts. It was intended to tackle those 'people taking advantage of the political and national situation, withholding payment to their neighbour for value received, withholding money due in various forms, whether through debts, rents, Land Commission annuities, or in any other form'. ${ }^{19}$ With bailiffs granted increased powers, landlords began to resort to the courts to have their rents paid. This put the new government in an invidious position; it could hardly be seen to favour the old landed class over the new order. If landlords were granted the opportunity to press for arrears or evict their tenants, the new government was likely to be accused of being no different to British governments in the past.

In January 1923 the first tentative steps had been taken towards the formulation of a new land bill as a matter of 'importance and urgency'. ${ }^{20}$ Agrarian grievances could only be addressed by the completion of land purchase and the compulsory acquisition and attendant redistribution of lands. Ostensibly the government recognised the precarious nature of its position and, knowing that legislation promising to complete land purchase and initiate compulsory land acquisition and redistribution might negate the popular support of the republicans and initiate a return to law and order, determined to press ahead with the introduction of a land bill.

If this land bill was to solve the land question in Ireland once and for all, it should have been very carefully formulated. It possibly was not - and this observation is not intended as a reflection upon the abilities or intentions of those who formulated it but rather upon the extreme complexities of the issues with which the bill had to deal and which would have required much longer than a few months' deliberation and planning (although, of course, few bills are actually afforded such a luxury). While Hogan was aware that it was unlikely to be the last land bill introduced to the Dáil, ${ }^{21}$ he hardly envisaged it would be followed by a dozen or so more over a forty-year period. It seems that the socio-political climate of the time dictated that it would have to be pushed through before the impending general election on 27 August 1923. In the aftermath of the Land Purchase and Arrears Conference of 10-11 April that had been established in an attempt to negotiate common ground between landlords and tenants, Hogan had announced to the government the mood of a significant proportion of the electorate:

They [the tenant representatives] informed the landlords in all moods and tenses that a great change had come; that they [the landlords] were now in a small minority, and an unpopular minority; that they [the tenants] could take the land from them for nothing if they wished; that the people meant to have the land cheaply, and that if the present

${ }^{18}$ Enforcement of Law (Occasional Powers) Act, 1923 (1923, no. 4) (1 Mar. 1923); District Justices (Temporary Provisions) Act, 1923 (1923, no. 6) (27 Mar. 1923).

${ }^{19}$ Kevin O'Higgins, Minister for Home Affairs, Dáil Éireann deb., ii, 971 (19 Jan. 1923).

${ }^{20}$ Ibid., ii, 592 (5 Jan. 1923).

${ }^{21}$ Ibid., iii, 1147-8 (28 May 1923). 
government did not meet the wishes of the people in this respect, they would put in a government the next time who would. ${ }^{22}$

The formal introduction of the land bill to the Dáil in May 1923 coincided with the ending of the Civil War and may very well have significantly contributed to the decline in support for the anti-treatyites' agrarian campaign. In a powerful speech Kevin O'Higgins, the Minister for Home Affairs, warned against recalcitrance:

Within the last year, under cover of activities against the Government, men have gone out in an entirely selfish, wilful and criminal spirit to seize land by the strong hand, or by the hand which they thought was strong ... [I will urge] on the Minister for Agriculture from my department, that the people who go out in that spirit, who go out in the defiance of the law and in defiance of the Parliament to press their claims by their own violence and their own illegalities be placed definitely outside the benefits of this Bill. ${ }^{23}$

Dáil rhetoric during the debate astutely emphasised that the introduction of the bill marked the end of the agrarian revolution, the beginning of which was dated, with some justification, to 1870 . In many respects, deputies from all parties were attempting to create something of a legacy for themselves: they, the first constituent members of a national parliament since the passing of the Act of Union, would, as one deputy forcefully put it, 'dispose of the last remnant of Irish landlordism'. ${ }^{24}$

On 8 August 1923 President W. T. Cosgrave introduced a special resolution to both houses of the Oireachtas:

... during the last two or three years a good deal of dislocation of the ordinary administration has been attributable to the land agitation ... This is a Bill on which the maximum amount of agreement has been brought to bear by all the parties to it ... But I think the general consensus of opinion in the Oireachtas and in the country is that the measure is one that will go far towards making for much more peaceful conditions and much more ordered conditions and for greater security and greater stability than perhaps any other measure we have had under consideration here. We consider that the public peace is ensured by the passing of this Bill. ${ }^{25}$

Cosgrave's speech was strongly suggestive of the fact that the bill would have a more salutary effect than even the Public Safety (Emergency Powers) Acts passed the same month. ${ }^{26}$ The introduction of such a special resolution could have caused a great deal more controversy than it did had its terms not specifically excluded the bill from the referendum clause of Article 47 of the 1922 constitution. ${ }^{27}$ Was the bill really that necessary as a means of ensuring public peace, or was it more of a political expediency at a crucial time in the

${ }^{22}$ Patrick Hogan, Report on the Land Purchase and Arrears Conference of 10-11 Apr. 1923, dated 17 Apr. 1923 (U.C.D.A., Blythe papers, P24/174).

${ }^{23}$ Dáil Éireann deb., iii, 1161-2 (28 May 1923).

${ }^{24}$ Ibid., cols $1147-8,1153$.

${ }^{25}$ Ibid., i, 1983-5 (8 Aug. 1923).

${ }^{26}$ An act to provide for the preservation of public safety and the protection of persons and property and for matters connected therewith or arising out of the present emergency (1923 no. 28) (1 Aug. 1923); An act to make provision for the immediate preservation of the public safety (1923 no. 29) (3 Aug. 1923).

${ }^{27}$ See Darrell Figgis's questioning of the legitimacy of the resolution, Dáil Éireann deb., iv, 1985-6 (8 Aug. 1923). 
genesis of the new state, or more particularly in the consolidation of the Cumann na nGaedheal party as the party of government? If the referendum clause was not bypassed, the bill could technically have been suspended for ninety days, which would have given landlords the time to follow through on the thousands of writs that allegedly had been processed during the previous months. This could possibly have had disastrous electoral consequences for the government in the general election fixed for 27 August. Back in April, Hogan had urged upon Cosgrave the necessity of an immediate introduction of the land bill before landlords began to issue writs for arrears of rent that would cause 'a very big row' ${ }^{28}$ If the bill was enacted, all arrears of rent up to the final gale day in 1920 would be immediately cancelled, all those accruing from that gale day to the one preceding the passing of the act would be compounded at 75 per cent of the total, and no proceedings against tenants for the recovery of arrears could be begun or continued after the passing of the act. It therefore made good political sense to have it enacted before the general election.

The special resolution was passed by both houses and the 1923 land bill passed into law on the following day, 9 August. $^{29}$ In the long term, this act and those which followed would redesign the social structure of Irish rural society; in the short term, it contributed to the return to more peaceful ways in the Irish countryside at least as much as any other legislative measure introduced by the Free State government in the first eight months of 1923.

\section{II}

The 1923 Land Act has primarily been associated with the completion of land purchase that had been begun by the British land purchase acts. ${ }^{30}$ It was, however, much more significant than a mere facilitator of the completion of land purchase. In its very ambitious attempt to solve the land question once and for all, it gave the newly constituted Land Commission ${ }^{31}$ powers to carry out the compulsory acquisition and redistribution of land. It recognised that the completion of land purchase was only one stage in the solving of the land question; the other stage, which was much more complex and would remain intractable, was the relief of congestion.

Post-independence agrarian grievances were underpinned by the prevalence of uneconomic farms throughout the country. Traditionally there has been a sense that these farms were concentrated almost exclusively along the western seaboard or in the so-called 'congested districts areas' that had been designated

\footnotetext{
${ }^{28}$ Memorandum on 1923 land bill prepared by Patrick Hogan for W. T. Cosgrave, 18 Apr. 1923 (N.A.I., DT S3192).

${ }^{29} \mathrm{An}$ act to amend the law relating to the occupation and ownership of land and for other purposes relating thereto (1923 no. 42) (9 Aug. 1923).

${ }^{30}$ See, for example, Lyons, Ireland since the Famine, p. 606; Murphy, Ireland in the twentieth century, p. 65; Fanning, Independent Ireland, p. 73; Jackson, Ireland 1798-1998, p. 283.

${ }^{31}$ Land Law (Commission) Act, 1923: an act to amend the law relating to the Irish Land Commission and to dissolve the Congested Districts Board for Ireland and transfer its functions to the Irish Land Commission and for other purposes connected therewith (1923 no. 27) (24 July 1923).
} 
under the 1891 land act as necessitating remedial rural development, particularly with regard to the reform of land structure. However, at independence an average of around 65 per cent of all agricultural holdings in each of the counties outside the designated congested areas came under the definition of 'uneconomic' as set out by the Land Commission, that is, below $£ 10$ valuation or roughly 20 acres of 'reasonable' land. ${ }^{32}$ The simultaneous existence of a variety of other interested social groups including the landless, evicted tenants or their representatives and I.R.A. veterans who felt that their contribution to the independence struggle entitled them to farm grants ensured that agrarian issues were certainly not going to go away. And, of course, with the recent extension of the franchise in 1918, these groups had all assumed increased electoral importance. Inevitably there was the temptation to manipulate land reform for political purposes because local and national politicians quickly came to realise that no other issue was as important to the rural mindset.

Thus no other state body was as important to rural Ireland as the reconstituted Land Commission. After 1923 it became the principal agent of social engineering in modern Ireland, and it may not be an exaggeration to claim that its impact on Irish rural society was matched only by that of the Catholic church. The commission had two main functions: first, to complete the transfer of tenanted lands by providing state funds for the purpose of vesting these holdings in the tenant purchasers as owners in fee simple subject to terminable land purchase annuities; second, to divide and redistribute land through the acquisition of untenanted estates (and later on holdings resumed from those who had purchased under previous land acts) and their division into appropriate parcels among selected allottees, either for the enlargement of uneconomic holdings or for the provision of new holdings for persons specified as being entitled to the same under the Free State / Irish Republic land acts.

In respect of the completion of the transfer of proprietorship, the sheer scale of the financial burden that the 1923 act placed upon the state and its willingness to carry that burden is stark evidence of the perceived importance of the land question to contemporaries. In May 1923 Patrick Hogan estimated that it was going to cost the state up to $£ 30$ million to complete land purchase at a time when the country was 'only just emerging from an atmosphere of unreason and irresponsibility'. ${ }^{33}$ This money could only be raised through a loan from the British government. ${ }^{34}$ In a Dáil speech in 1925 Hogan put the scale of the operation into perspective for his fellow T.D.s:

It is an enormous loan, when compared with ordinary development, say, with the development of the Shannon, a gigantic scheme, but at the outset which is only going to cost about five million pounds. Thirty million pounds for land purchase is a very expensive matter, very much more expensive than any other. ${ }^{35}$

As it happened, the completion of land purchase and division under the 1923 act cost considerably more. Professor David Seth Jones, whose recent work on land reform in independent Ireland has begun to challenge traditional doctrine,

${ }^{32}$ Report of the Estates Commissioners for the year from 1 April 1920 to 31 March 1921 , p. vi.

${ }^{33}$ Dáil Éireann deb., iii, 1147 (28 May 1923).

${ }^{34}$ Ibid., x, 1544 (26 Mar. 1925).

${ }^{35}$ Ibid. 
has provisionally set the figure at $£ 58$ million, a truly colossal figure for the implementation of any social policy, and this was really only the proverbial tip of the iceberg because subsequent land legislation cost considerably more. ${ }^{36}$ The need to seek such a huge loan from Britain in order to begin the process in 1923 - which Hogan believed was necessary to stabilise the countryside and thereby attract future long-term investment ${ }^{37}$ - undoubtedly constrained the political ambitions of Cumann na nGaedheal and, indeed, their expenditure in other areas of social policy.

But it was in the area of acquisition and division that the Land Commission impacted most upon the majority of families living in rural Ireland. By the time it published its final report in 1987 over 1.5 million acres had been acquired and redistributed under the various land acts from 1923, while another 840,000 acres acquired under previous land acts (for which the Land Commission became responsible after 1923) were also divided. This gives a total of 2.34 million acres. Given that there was at most 11.6 million acres of agricultural land in the twenty-six counties (that is, the area under crops, pasture and grazing), this represents a very significant 20 per cent of farmland affected by acquisition and division. ${ }^{38}$ If the 3 million acres vested in the new proprietors is taken into consideration (the difficulty here being that some of this area may also be included in the acquisition and division figures if farms were resumed by the Land Commission), this brings the total to almost 50 per cent of agricultural land subjected to Land Commission interference. Perhaps more significantly, 114,000 families benefited from having their holdings vested in them, while another 134,000 families (at least) benefited from enlargements, new holdings or accommodation plots, and so on. This represents a total of 248,000 families. It is difficult to put this figure into perspective, given the fluctuating numbers employed in agriculture over the extended period from 1923 to 1987, but, for example, in 1946 (the last census year before the end of the period covered by this paper) the total rural population was around 1.12 million persons, of which just under 250,000 were returned as farmers. ${ }^{39}$ Furthermore, for the years for which statistics are available (1937-78), the Land Commission migrated over 14,500 farmers on to lands totalling over 382,000 acres. ${ }^{40}$ In total, 54 per cent of the area acquired by the Land Commission in Kildare and 54 per cent in Meath was allotted to such migrants. ${ }^{41}$

Add to these figures the thousands of families who lost land through compulsory acquisition (not only landlords, but also many large farmers who had purchased their holdings under the British land acts) ${ }^{42}$ and it becomes very clear

\footnotetext{
${ }^{36}$ I would like to acknowledge Professor Jones's generosity in sharing his findings with me.

${ }^{37}$ Dáil Éireann deb., iii, 1150-51 (28 May 1923).

${ }^{38}$ Statistical abstract of Ireland, 1962 (Pr 6571), pp 68-9.

${ }^{39}$ Census of population of Ireland, 1946 (1949, P 9225), i, 18; ii, 10, 154-9.

${ }^{40}$ Reports of the Irish Land Commission, 1937-78; P. J. Sammon, In the Land Commission: a memoir, 1933-1978 (Dublin, 1997), pp 260-61.

${ }^{41}$ Department of Lands memorandum for the government: 'Review of Land Commission policy', July 1957 (N.A.I., DT S16265).

${ }^{42}$ One of P. J. Sammon's very interesting statistical appendixes shows, for example, that 170 (former) landlords had almost 238,500 untenanted acres acquired between 1923 and 1936 alone (Sammon, In the Land Commission, pp 264-78).
} 
that after 1923 the working of the Land Commission impacted positively or negatively on the vast majority of farmers in independent Ireland. If further evidence is required, it might be worth noting that in the 1940 s the Land Commission secretariat, which dealt with Land Commission correspondence, was receiving in excess of 400,000 letters per annum. ${ }^{43}$

It was actually the Land Commission's interference with proprietorial security that made it for many the 'bogeyman' of rural Ireland, particularly after the passing of the 1933 and 1946 land acts. ${ }^{44}$ The acquisition and division of farms became a notoriously divisive issue, pitting neighbour against neighbour. As late as 1971 Jim Tully (Meath, Labour) told the Dáil:

I ... think it is wrong that too much emphasis is put on the information given to a Land Commission inspector by people other than the applicant. There is a tendency on the part of everybody whose job it is to get information to go to a neighbour for information about a particular person. This is wrong. The applicant should be allowed to make his own case and to stand or fall on that case. Let him look for recommendations if he wants to but let us not have the situation where some of his neighbours who do not like him can put in a 'spoke' to try to prevent him from getting something to which he is morally entitled. ${ }^{45}$

It pitted the rights of the western migrants against local inhabitants in eastern counties such as Meath, leading to a great deal of local tension. At one stage in the late 1930s these tensions culminated in ugly street riots in Athboy, County Meath, as locals vented their anger towards 'land-grabbing' migrants. ${ }^{46}$ Around the same time S. J. Waddell (who had joined the Land Commission in 1909 and had risen to the position of land law commissioner by the mid-1920s) wrote in the introduction to his play Bridge Head (written under the pseudonym Rutherford Mayne): 'To deal justly with those who have to give up their land so necessary for the relief of the congests, to allot this land equitably to the numberless applicants and to install the migrants in the teeth of what is often determined and strenuous opposition, is not an easy task. ${ }^{47}$ In the actual play itself, one of his characters, a local man, informs the Land Commission inspector who has recently arrived in the area to divide an estate: 'You'd be wise to be putting no migrant up into that country. Begor the Rising that was in [nineteen] sixteen will be nothing to what's coming on yous if you plant strangers up in that bedlam.' ${ }^{48}$ Even more frightening was the factual case of the Land Commission inspector who received a death threat from a dissatisfied applicant who had been overlooked in favour of a migrant. ${ }^{49}$ And he was probably not the only one.

43 H. J. Monahan, 'Administration of land acts' in F. C. King (ed.), Public administration in Ireland (Dublin, 1945), p. 141; see figures above regarding population and farm households at this time.

${ }^{44}$ See David Seth Jones, 'Land reform legislation and security of tenure in Ireland after independence' in Éire-Ireland, xxxii-xxxiii (1987-8), pp 116-43.

${ }^{45}$ Dáil Éireann deb., cclvi, 509 (28 Oct. 1971).

${ }^{46}$ Ibid., lxxvii, 938 (8 Nov. 1939).

${ }^{47}$ Rutherford Mayne [S. J. Waddell], Bridge Head (Dublin, n.d.), p. v.

${ }^{48}$ Ibid., p. 3.

${ }^{49}$ Meath Chronicle, 27 Apr. 1935. 
III

During the 1920s and 1930s no other social issue was as important to political survival - not only that of individuals but also that of parties - as land division. Land became 'good business politically'. From 1923 to 1948 very few received land unless they were members of Fianna Fáil cumainn or Cumann na nGaedheal / Fine Gael clubs. ${ }^{50} \mathrm{~A}$ few examples will here suffice. In December 1924 John Lyons (Longford-Westmeath, Independent Labour) was under no illusions as to why Cumann na nGaedheal introduced the 1923 Land Act: 'You had the Land Act introduced for the purpose of election propaganda ... in order to safeguard the position in 1923 by getting a big majority for the government. ${ }^{51}$ In 1929 F. J. Carty (Leitrim-Sligo, Fianna Fáil) claimed that

When land is being divided in my constituency, it is not the most deserving applicants that secure allotments. The principal key-men and supporters of Cumann na nGaedheal invariably receive first preference ... Prominent followers of Cumann na nGaedheal were brought, some of them a distance of three or four miles, and given land at Raughly on the Gore Booth estate; while the claims of other small landholders and fishermen were ignored. Quite recently when land was being divided on the Mitchell estate near Dromore West, the local Cumann na nGaedheal secretary was brought in from an outside estate and given a section of these lands, to the exclusion of more deserving applicants including those who formerly obtained conacre tillage there. ${ }^{52}$

After Fianna Fáil took office in 1932 it was now the turn of the Fine Gael-led opposition strenuously to attack the government's land division policy. In July 1936 James Dillon (Donegal, Centre Party) declared in the Dáil:

The Deputy [Mr Davin] knows as well as I do that Fianna Fáil T.D.s have been called down to discuss with local Fianna Fáil cumainn the distribution of land in a particular parish; that they have gone down and let it be widely known that at the cumann meeting over which they were presiding a discussion took place as to the division of so-and-so's land, and that Deputy so-and-so is going to use his influence - that is the phrase - to get that land divided. ${ }^{53}$

Davin did not refute the allegations.

Two further examples are enlightening, even though one of them falls outside the time constraints of this article. In 1945 Oliver J. Flanagan (Leix-Offaly, Monetary Reform) admitted in the Dáil that some years previously he had been secretary of his local Fianna Fáil cumann when an estate known as Robinsons of the Rock was being divided. A Land Commission inspector allegedly called to Flanagan's home and informed him that he "was the first man in that district that he had received instructions from the minister [for lands] to come to because I was secretary of the Fianna Fáil club'. In the subsequent scheme of division, Flanagan claimed that 'on every occasion the applicant's political affiliations were investigated' and concluded:

I would not be speaking with a clear conscience if I did not openly admit that, when I was secretary of a Fianna Fáil club, I saw the most corrupt and the most disgraceful things

\footnotetext{
${ }^{50}$ Terence Dooley, 'The land for the people': the land question in independent Ireland (Dublin, 2004), pp 201-27.

${ }^{51}$ Dáil Éireann deb., ix, 2591 (12 Dec. 1924).

${ }^{52}$ Ibid., xix, 665-6 (18 Apr. 1929).

${ }^{53}$ Ibid., 1xiii, 1969 (24 July 1936).
} 
done to keep individuals out of land that I have ever known in all of my years of public life..$^{54}$

Up to the late 1950s it was practice for inspectors to set out in the official list of applicants for allotments of lands, the names of the persons who were recommending these applicants. In 1957 Erskine Childers, then Minister for Lands, directed that this practice should cease. Ambiguously, he argued that the practice had not influenced the Land Commission in drawing up their final lists of allottees. If that was the case, why ban it? Furthermore, during the speech in which he advocated that the practice should cease, he attempted to draw attention to the ineffectiveness of the process:

In one typical estate, 11 applicants who had not solicited recommendations were successful as compared with only five who had solicited recommendations. In another case, nine were successful without representations as compared with only two on whose behalf representations were made. In yet another case, six were successful without representations as compared with only three who had solicited recommendations. ${ }^{55}$

Surely a success rate of 38 per cent (and no doubt one grossly understated) among those who had representations made on their behalf speaks for itself. At any rate, Childers decided to alter radically the practice of representations. In his first Department of Lands estimate speech in 1957 he informed the Dáil that he would be sending a letter to all T.D.s to remind them that the selection of allottees was an excepted matter over which the Minister for Lands had no control. P. J. Sammon, a principal officer in the Land Commission at the time, maintains that this new situation lasted only a matter of weeks: 'The Fianna Fáil T.D.s were up in arms and following a party meeting, the minister was forced to drop this approach and to revert to the status quo ante. ${ }^{56}$

Obviously it was important for T.D.s to create the impression that they had significant influence over the decisions reached by the Land Commission with respect to local acquisitions and divisions. It made good political sense to be seen to be supporting the claims of their constituents. The most solid indicator of this was the amount of time spent on land-related debates and questions in the Dáil. The present author has looked at almost 8,500 land-related references in the Dail debates for the years $1923-73$. The majority of references $(5,300$, or 62 per cent) were for the period from 1923 to 1939 , an average of 312 per calendar year. And of the 5,300, the bulk of these (almost 75 per cent) were questions put by individual T.D.s relating to the acquisition and division of lands in their constituencies. This number, it should be added, does not take into consideration the fact that in numerous instances a T.D. in a single question would inquire about the possibility of the division of a dozen or more estates in his/her constituency which, if enumerated as separate references, would greatly multiply the total.

Proportionately more time was spent on discussing land issues than any other single issue from 1923 to 1939 , with the exception of constitutional reform for a period in the 1930s (but, of course, after the constitution was enacted in 1937, the land reform question remained active for another forty years). The annual vote on the Land Commission estimates from 1923 to 1948 consistently attracted contributions from the majority of deputies in the Dáil who represented rural

\footnotetext{
${ }^{54}$ Ibid., xcvi, 2456 (25 Apr. 1945).

${ }^{55}$ Ibid., clxvi, 158 (24 Apr. 1957).

${ }^{56}$ Sammon, In the Land Commission, p. 126.
} 
constituencies. (In general, the city-based T.D.s stayed aloof from such debates; J. J. Byrne (Dublin North, Cumann na nGaedheal) announced in the Dáil in 1928: 'I did not intend to take any part in this debate at all, for I always considered that the city man knows very little about land.' $)^{57}$ On 24 July 1924, so much time was spent on the issue of land division that Major Bryan Cooper's (County Dublin, Independent) only contribution to the debate was to 'remind the Dáil that there are some thirty votes yet to be discussed'. ${ }^{58}$

While it is easy to be cynical about T.D.s' motives, methods and success rates, at the same time it would be foolish to underestimate the actual significance of political manoeuvring in the determination of land division schemes. As we shall see below, pressure could be exerted by a local community through a Fianna Fáil cumann or a Cumann na nGaedheal branch that would have been extremely difficult for a Land Commission inspector to counter.

The very policy of the Land Commission and its implementation at local level opens up a range of issues that cannot possibly be dealt with in an article of this length but which require attention elsewhere. For example, what light might the investigation of the land question in independent Ireland throw upon the complex issue of voting patterns? Fianna Fáil certainly recognised at an early stage the importance of land division to its prospective electoral success. Back in the $1880 \mathrm{~s}$ when the home rule movement merged with the land movement the merger gave the former a much greater national impetus. This was a fact not lost on Eamon de Valera, who, at the Fianna Fáil ard-fheis in October 1931, said that

he remembered a great deal of argument as to whether the movement for Home Rule was being advanced or retarded by linking up with the fight for the land. There was [now] a certain linking up because it was thought that by doing so there would be brought to the national movement a support which it might not otherwise get. ${ }^{59}$

The fifth plank of Fianna Fáil's policy as enunciated at its inaugural meeting in April 1926 - 'to establish as many families as practicable on the land' ${ }^{\prime 60}$ - is not only the one of most relevance here, it was also the one that appealed most to the small farmers and agricultural labourers who were more concerned with improving their standards of living than, for example, achieving a thirty-twocounty Ireland. In ideological terms, Fianna Fáil, by promoting this policy, regarded itself as following in the tradition of Sinn Féin and the first Dáil Éireann. ${ }^{61}$ In more practical terms, Fianna Fáil was creating a power base in rural

${ }^{57}$ Dáil Éireann deb., xxiii, 88 (18 Apr. 1928).

${ }^{58}$ Ibid., viii, 2189 (24 July 1924).

${ }^{59}$ Irish Press, 29 Oct. 1931.

${ }^{60}$ Richard Dunphy, The making of Fianna Fáil power in Ireland, 1923-1948 (Oxford, 1995), p. 83.

${ }^{61}$ Frank Aiken, for example, would later claim that 'One of the principal objects for which Fianna Fáil was founded was to establish on the land as many families as practicable. This was also one of the fundamental objects of the old Sinn Féin movement and of the First Dáil.' See Dáil Éireann deb., xlviii, 2381 (13 July 1933); also corrected typescript copies of a speech by Frank Aiken introducing the 1933 land bill to Dáil Éireann, Aug. 1933 (U.C.D.A., Aiken papers, P104/3301). 
constituencies that was founded on numerical strength. Socio-economic and cultural objectives were, therefore, very much tied to a land policy whose key aims were: to settle as many families as was practicable on the land; to keep them there (as aspired to in the 1937 constitution) in economic security and free from privation; to maintain economic self-sufficiency through a tillage programme that was suited to a small-farm economy (which by extension meant getting rid of the graziers); and to promote the type of idyllic rural culture as espoused by de Valera.

By the early 1930 s, essentially because of competition for votes, Fianna Fáil cumainn and Cumann na nGaedheal / Fine Gael clubs were organising their members and presenting applications on their behalf to the Land Commission. Most of the preliminary inquiries about future estate divisions were probably made discreetly at political gatherings, in the local pubs and political clinics, at funerals, weddings and a variety of other local community events. These organisations then kept a close eye on developments, particularly when an inspector arrived in an area. The establishment of clubs and cumainn gave a formal structure to the lobbying process. In 1927, for example, the Fianna Fail ard-fheis recommended that

cumainn should pay special attention to the work of supplying their teachtai [T.D.s] with reliable information concerning matters of local importance, of which they should be acquainted. Persons wishing teachtai to take action on their behalf should be encouraged to approach them through the cumainn. ${ }^{62}$

In 1937 the president of the Dunboyne Fianna Fáil cumann in Meath referred to the recent division of a 600 -acre estate in the area:

If Fianna Fáil members got more land than people who were not members it was because the local cumann looked after the interests of its members. It saw that the claims were put forward in an intelligent way and submitted to the Land Commission in a proper manner. ${ }^{63}$

In turn, the officers of the local cumainn, it seems, were adequately catered for in local land division schemes for their contribution to the party. In November 1946 de Valera wrote a most revealing letter to Patrick Moroney in Limerick, who had just completed some valuable organisational work on the party's behalf:

I have yours of October 21 st and am glad to note that you will have the local cumann registered as soon as possible. I have taken up the question of a further allotment for you with the Minister for Lands and you may be assured of my best efforts on your behalf. ${ }^{64}$

Meanwhile Cumann na nGaedheal's relationship with the electorate (or at least with some of the 40 per cent or so of it who had given their first preferences for the pro-treaty party in the 1922 and 1923 elections) had been soured by the slow progress of land acquisition and division. Its continued protection of the largefarmer interest did not endear it to the more numerous smallholders. P. W. Shaw (Longford-Westmeath, Cumann na nGaedheal) alleged in the Dáil in 1927 that

${ }^{62}$ Fianna Fáil: second annual ard-fheis, 1927: report of proceedings, p. 5 (U.C.D.A., P176/741).

${ }^{63}$ Meath Chronicle, 16 Oct. 1937.

64 'Ard rúnaí' to Patrick Moroney, 25 Nov. 1946 (U.C.D.A., P176/62 (67)). According to the Fianna Fál research office, Eamon de Valera held this position within the party at this time, and the letter was undoubtedly sent by him. 
the Cumann na nGaedheal organisation had lost almost forty branches in County Westmeath as a result of the party not delivering on its land division policies there. ${ }^{65}$ Indeed, by the early 1930s Cumann na nGaedheal was being accused of not delivering on its land division policies anywhere. From 1923 to 1932 the Land Commission had acquired almost 331,000 untenanted acres and redistributed them to almost 16,600 allottees (excluding lands previously acquired by the estates commissioners and the Congested Districts Board). An annual average of almost 37,000 acres acquired and redistributed to an average of 1,844 allottees may seem impressive enough, but it was by no means sufficient to satisfy land-hungry contemporaries.

In many ways Cumann na nGaedheal rhetoric on the 1923 Land Act had been much more revolutionary in its expressed intent than was the actual process of acquisition and redistribution of lands during its term of office. Compulsory acquisition was not to apply to certain categories of property: lands purchased under previous land purchase acts or at that stage subject to a prior purchase agreement that had not been finalised; lands which were residential or formed part of a demesne, home farm, ${ }^{66}$ park, garden or pleasure ground; untenanted lands purchased under the 1869 Irish Church Act for less than $£ 2,000$; untenanted lands which had potential as building ground; lands held in trust for the state or government departments; and, finally, glebe lands which were in the occupation of 'ecclesiastical persons'.

The exceptions, in theory at least, benefited to some extent the remnants of the old landed class, allowing them to retain the trappings of demesne lands and the untenanted lands which some of them had sold and repurchased under the terms of the 1903 Irish Land Act. These safeguards were undoubtedly a gesture to the British government; in 1925 Patrick Hogan had told the Dáil that the British government, during negotiations regarding the financing of the act, had 'made no secret that they have the interests of the landlords at heart' ${ }^{67}$ The 1923 act made two further significant exceptions: untenanted lands which were stud farms and 'untenanted land which is intermingled with woodland . . . the acquisition of which would be detrimental to the preservation of woodland and to the interests of forestry' could not be acquired. ${ }^{68}$ Few of the great houses in Ireland did not have demesnes which had untenanted lands intermingled with woodland.

Regarding stud farms, this exception was understandable at the time, for the equine and horseracing industry was growing in importance and the government was well aware of the need to continue to promote it. But this exclusion also offered an opportunity to many of the great landowners of the past to continue to hold on to untenanted lands by establishing stud farms. In some cases these stud farms operated in name only; in other cases they were quite successful. By the late 1920s Lord Dunraven's Fort Union Stud at Adare was highly successful, as was Charles Moore's stud at Mooresfort in Tipperary; the Marchioness Conyngham established a stud at Slane, Sir Gilbert Greenall continued breeding

${ }^{65}$ Dáil Éireann deb., xxii, 889 (7 Mar. 1927).

66 'A farm used for the convenience or advantage of the owner's residence and in connection therewith and not merely as an ordinary farm for the purposes of profit' (Land Act, 1923).

${ }^{67}$ Dáil Éireann deb., x, 1544 (26 Mar. 1925).

${ }^{68}$ Land Act, 1923. 
horses and pedigree cattle at Kilmallock in Limerick, and Lord Mayo established an extensive stud farm at Palmerstown. ${ }^{69}$

The exceptions listed in the 1923 act also benefited the large farmers who had bought out their holdings under the terms of the British land acts and who formed the main support basis for Cumann na nGaedheal. If the Land Commission were to take up purchased lands (hereafter referred to as vested lands, for they had already been vested in the Land Commission under previous land purchase acts), the proprietor had to be provided with a new holding which in the opinion of the Land Commission . . . shall be equally suitable for the said proprietor or tenant and of not less value than the declared land'. ${ }^{70}$ Furthermore, the Land Commission would not compulsorily acquire land from an owner 'so long as there [was] other unacquired land in the same locality suitable for relieving congestion which [did] not come within the exceptions'.$^{71}$ If the owner of a parcel of untenanted land vested in the commission had worked it 'as an ordinary farm in accordance with proper methods of husbandry', and it was not required for the purposes of enlargement or the relief of congestion, he was allowed to repurchase it from the commission providing that the vested parcel plus other lands in his ownership did not exceed $£ 3,000$ in value.

Similarly, if the commission acquired land from an individual, it could also purchase demesne or other land in his possession adjacent to the acquired land and then resell it to the owner 'as if he were a person to whom advances might be made for the purchase of a parcel of land under this act' ${ }^{72}$ While all the excepted lands, other than those held in trust for the state or government departments, could be vested in the Land Commission if it decided they were required for the relief of congestion, the commission rarely brought this into play during the administration of Cumann na nGaedheal from 1923 to 1932. It is worth noting that from 1923 to 1932 the Land Commission resumed 106 farms with a total acreage of 21,555 acres, while it resumed 542 farms totalling 72,700 acres during Fianna Fáil's administration from 1932 to $1948 .{ }^{73}$ The annual average rate of acquisition under Fianna Fáil was, therefore, almost three times as great as that under Cumann na nGaedheal; the annual average acquisition in terms of acreage was almost twice as much; and the average size of farms acquired fell from 203 acres under Cumann na nGaedheal to 134 acres under Fianna Fáil.

It has reasonably been argued that one of the main reasons for the decline of Cumann na nGaedheal in the early 1930s was its commitment to the large farming class in its perceived attempt to maintain Ireland 'as an agricultural appendage of the U.K. economy' ${ }^{74}$ It is true that the party had done very little to attract the support of the small farming classes or the landless, and less still to stem the rising tide of poverty in rural Ireland. The transfer of proprietorship was much slower

${ }^{69}$ F. F. MacCabe and T. E. Healey, 'Racing, steeplechasing and breeding in Ireland' in Charles Richardson (ed.), British steeplechasing (London, 1927), pp 294-6; Terence Dooley, The decline of the big house in Ireland: a study of Irish landed families, 1860-1960 (Dublin, 2001), pp 267-8.

${ }^{70}$ Land Act, 1923.

${ }^{71}$ Ibid.

${ }^{72}$ Ibid.

${ }^{73}$ Extracted from Reports of the Irish Land Commission, 1923-48.

${ }^{74}$ Dunphy, Rise of Fianna Fáil, p. 21. 
than anticipated. Demands for additional lands from small farmers and lands for the landless agricultural labourers had not been met as had been anticipated. Credit was largely unavailable to either group - they did not have the necessary collateral to secure loans - while large farmers benefited from the facilities of the Agricultural Credit Corporation established in 1927. Small farmers could not hope to expand or even improve their holdings (no subsidies, for example, were available for pig farming, an integral part of the small farming economy) ${ }^{75}$ and agricultural labourers, whose wages were actually declining during the 1920s, had obviously very little hope of purchasing lands on the open market.

Furthermore, Cumann na nGaedheal's limited protection of Irish industry and its continued promotion of pastoral agriculture over tillage had contributed towards an increase in emigration levels once again in the 1920 s. $^{76}$ Cumann na nGaedheal, therefore, alienated the support of the small farming communities, particularly in the west. These communities began to look for alternative representation, and so looked increasingly towards Fianna Fáil.

In the lead-up to the 1932 general election Fianna Fáil promised a revolutionary programme of land acquisition and division. In power, Fianna Fáil's majority was dependent upon the support of Labour and was too tenuous to introduce the radical type of land legislation that was necessary. How much of a coincidence was it that in January 1933 de Valera called a snap general election after the party had clearly publicised the fact that the expediting of land acquisition and division was dependent upon a new land act? No fewer than seven resolutions (out of a total of forty-five) passed at the Fianna Fáil ard-fheis in November 1932, for example, related to land acquisition and division and the working of the Land Commission. ${ }^{77}$

In the general election that followed in January 1933 Fianna Fáil captured an extra five seats, giving it a safe overall majority. In 22 out of the 25 rural constituencies Cumann na nGaedheal's share of first-preference votes had declined rather dramatically, in fourteen of them by at least 10 per cent. Its losses were greatest in western constituencies such as Donegal, Clare, Galway, Leitrim-Sligo, Roscommon and Mayo North and South where Cumann na nGaedheal had been unsuccessful in relieving congestion; in the east-midland counties of Longford-Westmeath, Louth, Meath and Carlow-Kilkenny and the south-midland county of Tipperary, where large grazier and dairy farms continued to exist; and in the border counties of Monaghan and Cavan, where there was a very high concentration of smallholders clamouring for more economically viable holdings. In 24 out of the 25 constituencies (Cork West being the exception) Fianna Fáil candidates secured a higher percentage of firstpreference votes than their Cumann na nGaedheal opponents (an average of 48.2 per cent to Cumann na nGaedheal's 28.3 per cent). In 17 out of the 25 constituencies Fianna Fáil's share of first preferences over Cumann na nGaedheal was in excess of 20 per cent. Again, these were constituencies where land acquisition and division most likely played a key role in determining election results: Cavan, Clare, Cork East, Cork North, Donegal, Galway, Kerry,

\footnotetext{
${ }^{75}$ Ibid., p. 204.

${ }^{76}$ Enda Delaney, Demography, state and society: Irish migration to Britain, 1921-1971 (Liverpool, 2000), p. 60.

${ }^{77}$ Fianna Fáil: seventh annual ard-fheis 1932: report of proceedings (U.C.D.A., P176/746).
} 
Leix-Offaly, Limerick, Longford-Westmeath, Louth, Mayo North, Mayo South, Meath, Monaghan, Roscommon and Tipperary. ${ }^{78}$

The 1933 Land $\mathrm{Act}^{79}$ provided the Land Commission with more draconian powers regarding the compulsory acquisition of lands and allowed for the compulsory acquisition of purchased farms as well as untenanted estates, with limited restrictions. Patrick Hogan attacked the 1933 bill, with some justification, as being 'a purely political' one, pandering to the small-farmer and labouring classes in an attempt to secure votes. ${ }^{80}$ Land League-type rhetoric characterised the opposition's attack on the bill's contents, which the opposition claimed threatened tenurial security. In 1936 James Dillon (elected for Donegal as a Centre Party T.D. in the 1933 election) told the Dáil:

Hitherto, the Land Commission has been looked-up to by the people as their friend and champion as against the landlords. It is now becoming an infinitely worse landlord than Clanricarde ever was. You shake the confidence of the people in the personnel of the Land Commission if you make the Land Commission appear in the minds of the people as a menace and a threat to their fixity of tenure; you are going irretrievably to injure the Land Commission as a power for good in this country and that would be a great disaster. ${ }^{81}$

After 1933 farmers had to live with the fear that the Land Commission might resume their holding if it was large enough to be needed for the relief of local congestion, or if a land-hungry neighbour reported that it was not being worked in a satisfactory manner, or if the farmer fell on hard times and was unable to repay his annuities owing to any one of a variety of causes such as economic depression, illness or infirmity. It was a disturbing fact, as Professor George O'Brien told the Banking Commission in 1935, that

The question of whether a person will continue in possession of his holding at the present time in the last resort depends on the opinion of some official guided by some policy regarding the utility or otherwise of the type of agriculture he is pursuing. ${ }^{82}$

More crucially, the 1933 Land Act should perhaps be viewed in light of the stimulus it gave to the growth of the Blueshirts. The exact nature of the role of the wider land question in the rise of the Blueshirts has not yet been satisfactorily elucidated. Historians are in agreement that the movement was dominated by large farmers and graziers who were determined to protect their interests from the full rigours of de Valera's tariff war with Britain. ${ }^{83}$ The significance of the

${ }^{78}$ Statistical information drawn from B. M. Walker (ed.), Parliamentary election results in Ireland, 1918-92 (Dublin, 1992).

${ }^{79}$ An act to amend generally the law, finance and practice relating to land purchase, and in particular to make further and better provision for the execution of the functions of the judicial and lay commissioners of the Land Commission and to provide for the provisions of the purchase annuities and certain other annual payments and for the funding of arrears thereof, and to provide for other matters connected with the matters aforesaid (1933 no. 38) (13 Oct. 1933).

${ }^{80}$ Dáil Éireann deb., xlviii, 2396 (13 July 1933).

${ }^{81}$ Ibid., 1x, 715 (3 Feb. 1936).

${ }^{82}$ Commission of enquiry into banking, currency and credit: memoranda and minutes of evidence, ii (1938), p. 1164.

${ }^{83}$ See Mike Cronin, 'The socio-economic background and membership of the Blueshirt movement, 1932-1935' in I.H.S., xxix, no. 114 (Nov. 1994), p. 239; Paul Bew, Ellen Hazelkorn and Henry Patterson, The dynamics of Irish politics (London, 1989), p. 52. 
'economic war' to the growth in the Blueshirt movement is accepted, but it is also worth considering to what extent the threat to the proprietorial security of large farmers posed by the 1933 Land Act contributed to this growth.

In his analysis of the socio-economic backgrounds of a sample of Blueshirts (admittedly a small one), Mike Cronin has found that the majority came from families with under sixty acres who, he concludes, could not be classified as large farmers. However, his upper threshold in this case is too high; in the early $1930 \mathrm{~s}$ sixty-acre farms were actually almost three times the size of the standard Land Commission holding, which means that they were, in fact, considered very large farms at the time which could be targeted for resumption and redistribution if they were deemed necessary for the relief of congestion. In fact one-third of Cronin's sample owned in excess of ninety-one acres. The largest influx of members to the Blueshirts occurred between 1932 and 1934, with recruits pouring into their ranks in 1933, the year that Fianna Fáil introduced its first land act, a measure that threatened the proprietorial rights of the large farmers much more than the previous Free State land acts had done. ${ }^{84}$

When the terms of the 1933 act became effective, the rate of acquisition and division increased dramatically. For the year ended 31 March 1935 an unprecedented 102,000 acres of untenanted lands were divided among 6,244 allottees. ${ }^{85}$ In the following year the achievement was even greater: 104,000 acres among 7,712 allottees. For the first five-year period of Fianna Fáil's administration (ending 31 March 1937) almost 353,000 acres were divided among 25,802 allottees, over 100,000 acres more than in the preceding five-year period. Hardly surprisingly, Cumann na nGaedheal, defending the proprietorial rights of large farmers, argued that Fianna Fáil's radical land acquisition and redistribution policy was tantamount to 'the purest of communism'. ${ }^{86}$

Similarly, Cronin was surprised to find that 'counties such as Meath and Mayo where there was an absence of large landowners ... . saw big upturns in membership' of the Blueshirts in the early 1930s. ${ }^{87}$ There may have been a numerical absence of large landowners, but the bulk of the land in these counties was held by substantial proprietors whose holdings were targeted by Fianna Fáil after 1932 for acquisition and redistribution, in Mayo for local congests, in Meath for those migrants who would be moved from the west. By 1982, when the Land Commission's work of acquisition and division had effectively ended, 637 untenanted estates or purchased holdings had been acquired by the Land Commission in Meath (totalling 52,657 acres) and 1,573 in Mayo (totalling 48,828 acres). Mayo had the highest number of holdings acquired/resumed in the country, while Meath was in fifth place. Meath had the second-highest acreage acquired/resumed, while Mayo had the third-highest (both behind Galway). ${ }^{88}$ It is quite possible that the threat of the acquisition of their estates drove many of the large landowners from these counties into the Blueshirts.

When the record acquisition and division statistics could not be matched after 1936 for a variety of reasons, not least of which was the unavailability of large

${ }^{84}$ Cronin, 'Blueshirt movement', pp 237-8.

${ }^{85}$ Report of the Irish Land Commission, 1934-5, p. 5.

${ }^{86}$ Dáil Éireann deb., xlix, 937 (1 Aug. 1933).

${ }^{87}$ Cronin, 'Blueshirt movement', p. 239.

${ }^{88}$ Report of the Irish Land Commission, 1981-2, pp 10-11. 
untenanted estates, another bout of disillusionment, frustration and disappointment engulfed the small farmers of the west. In the 1937 general election Fianna Fáil support there fell by 8 percentage points from its 1933 level. This was hardly coincidental, yet it has not been highlighted. Similarly, when land acquisition and division was temporarily halted during the Emergency, Fianna Fáil support in the west plummeted to 43 per cent in the 1943 election, which represented a fall of 18 percentage points from 1933.

Another fall-out of Fianna Fáil's failure to deliver on its promises of land division was the establishment of Clann na Talmhan in 1938. While the Clann claimed to have other agendas besides the land question, it was essentially upon this issue that its initial success was based. In the 1943 general election Clann na Talmhan secured ten seats: one in Cavan, one in Cork North, one in Cork West, one in Donegal East, one in Galway East (where its founder, Michael Donnellan, topped the poll), one in Kerry North, two in Roscommon, one in Tipperary, and one in Wicklow. ${ }^{89}$ The successful candidates' share of first-preference votes cast ranged from 5.5 per cent in Tipperary to Donnellan's 25.6 per cent in Galway. In Roscommon the two successful candidates took 31 per cent of the total first preferences. In Kerry North the successful Clann na Talmhan candidate took 13.6 per cent of the first preferences, with his running-mate, who narrowly missed out on election, taking another 13 per cent. In Cavan, Cork North, Cork West and Wicklow the Clann candidates took an average of 15.6 per cent of first preferences. ${ }^{90}$ This election was to mark the high point of the party's electoral success.

\section{V}

A characteristic post-war desire for change initiated a shift away from Fianna Fáil for a variety of reasons already set out by historians, including inter alia a serious balance-of-payments deficit in 1947, disillusionment that the post-war economy was not improving, a disastrous winter in 1947, a serious energy crisis as coal supplies from Britain were curtailed, and perhaps popular reaction to Fianna Fáil's growing arrogance, the need to demonstrate that power was revocable and that Ireland would not be turned into a one-party state. ${ }^{91}$ However, historians have failed to consider another crucial element in this shift - the party's ultimate failure to deliver upon its pre-1932 promises of land division.

Furthermore, the 1948 general election was fought amidst huge controversy that surrounded the terms of the 1946 Land Act that gave powers to the Land Commission to resume holdings from allottees who had not farmed them to the satisfaction of the Land Commission. Most of these holdings had been given to landless men in record numbers during the early years of Fianna Fáil's administration. ${ }^{92}$ With little experience of running farms, and even less capital,

\footnotetext{
${ }^{89}$ Information extracted from Walker (ed.), Parliamentary election results, 1918-92, pp $154-61$.

${ }^{90}$ Ibid.

${ }^{91}$ See, for example, J. A. Murphy, 'The Irish party system, 1938-51' in K. B. Nowlan and T. D. Williams (eds), Ireland in the war years and after, 1939-51 (Dublin, 1969), p. 158; Townshend, Ireland: the twentieth century, p. 159.

${ }^{92}$ Seán Moylan to de Valera, 1 Sept. 1943 (N.A.I., DT S12890); Moylan to Lemass, 5 May 1944, quoted in W. F. Nally to Pádraig Ó Cinnéide, 16 May 1944 (ibid.).
} 
many of these allottees floundered as farmers, having succumbed to the ravages of economic depression and the calamitous effects of a prolonged 'economic war' with Britain. Fianna Fáil, by threatening to take back forcibly lands that it had allotted, was acting in a way that was tantamount to evicting tenants during the land war of the 1880s. Just as galling for the small farmers of the west was the fact that by 1948 Fianna Fáil was beginning to play ball with the large farmers and the ranchers. In June 1948 Bernard Commons (Mayo South, Clann na Talmhan) claimed that Fianna Fáil's proposed land division policy in 1932 had assured it of the support of the majority of small farmers in the country and the hostility of every rancher, but in the interim in his constituency

slowly and surely ... the position changed and, in 1948, in the constituency which I represent I found that 99.9 per cent of the ranchers of the locality were loyal and enthusiastic supporters of the Fianna Fáil Party and that 95 per cent of the uneconomic holders were up in arms against the Fianna Fáil Party because of their failure to provide them with what they wanted. ${ }^{93}$

It is also true that by this stage certain influential members of Fianna Fáil had come to recognise the negative impact that the complete break-up of large farms could have on the Irish agricultural economy if land acquisition and division was to continue on the pre-Emergency scale. ${ }^{94}$ Seán Moylan as Minister for Lands (1943-8) advocated the decelerating of land acquisition and division and promoted the gradual movement away from traditional Fianna Fáil land division policy. In 1944 he wrote to Seán Lemass: 'Some people hold the view that the greater number of acres of land divided the greater the success. I don't hold that view. The creation of records has resulted in ill-advised schemes the evils of which are now apparent. ${ }^{.95}$

Moylan, Lemass and many of their contemporaries were aware that small-farm life could no longer be painted in idyllic terms; harsh reality had intervened in the form of reports by agricultural experts and experienced members of the Land Commission. ${ }^{96}$ In 1945 a committee (appointed three years earlier to consider agricultural policy in the aftermath of the Emergency) under the chairmanship of Professor T. A. Smiddy reported that 'the prosperity of the agricultural industry in this country will depend in the future, as it has done in the past, on intensive production of livestock and livestock products and on the disposal of a large proportion of such products in the export market' and recommended the expansion rather than the contraction of the livestock market. ${ }^{97}$

In 1947 the Cabinet Committee on Economic Planning argued that the small standard farms of $£ 20$ poor law valuation (or twenty-five acres of good land) were 'only subsistence holdings which add little to the agricultural wealth of the country, provide little or no exportable surplus and allow no appreciable cash

\footnotetext{
${ }^{93}$ Dáil Éireann deb., cxi, 352-3 (3 June 1948).

${ }^{94}$ Committee of enquiry on post-Emergency agricultural policy: reports on agricultural policy, 1945 (1945, P 7175), pp 84-5.

${ }^{95}$ Moylan to Lemass, 5 May 1944, quoted in W. F. Nally to Pádraig Ó Cinnéide, 16 May 1944 (N.A.I., DT S12890).

${ }^{96}$ For a fuller discussion see Dooley, 'The land for the people', pp 121-31.

${ }^{97}$ Committee of enquiry on post-Emergency agricultural policy: reports on agricultural policy, 1945 (1945, P 7175), pp 84-5.
} 
margin'. These holdings were now deemed uneconomic. ${ }^{98}$ There was a clear change in political thinking here, for the committee argued that to divide 200acre farms into holdings of less than thirty acres had no lasting effect: 'Quite apart from any other result, at the first opportunity these small holdings will tend to coalesce once more under the force of economic attraction.' 99 The highly influential Department of Finance similarly argued that before any further reduction in the small number of large farms now left in the country was brought about 'the possible repercussion on the agricultural economy as a whole should receive exhaustive examination' ${ }^{100}$ Finance further suggested that the Land Commission should not acquire any more land for division except in the congested districts. ${ }^{101}$

Some Fianna Fáil traditionalists now acknowledged that in a country where so many smallholdings had been created, it was necessary to preserve the remaining large farms in the richer agricultural areas to provide a market for the cattle produced in the poorer agricultural lands of the west and south. ${ }^{102}$ But the proposed abandonment of Fianna Fáil's traditional land policy was not well received among the less well-off small-farming community and undoubtedly had a negative impact upon the party's fortunes at the polling booths in 1948 . When returned to power in 1951, Fianna Fáil kept the portfolio for lands in the hands of traditionalists such as Thomas Derrig (1951-4) and Michael Moran (1959-68), who both favoured a land reform policy that focused upon acquisition and division.

This article has argued that Irish society remained animated by land issues long after independence. The completion of land purchase under the 1923 Land Act was not the final solution to a land problem that essentially had more to do with the economic viability of farms than peasant proprietorship. For that reason compulsory land acquisition (attempted only on a very limited basis before independence) and division came to dominate Irish rural society for much of the twentieth century.

This effectively meant that the reconstituted Land Commission became the most important (and controversial) government body operating in independent rural Ireland. It acted as a facilitator of social engineering, compulsorily acquiring lands from traditional landlords, large farmers, graziers and negligent farmers and passing it on to smallholders, former employees of acquired estates, evicted tenants and their representatives, members of the pre-truce I.R.A. and the landless. It moved over 14,500 farmers on to lands totalling over 382,000 acres. Yet despite the enormous impact of the Land Commission upon Irish society for

\footnotetext{
${ }^{98}$ Department of Lands memorandum for the government on land division policy, Apr. 1947 (N.A.I., DT S6490B/1).

${ }^{99}$ Ibid.

${ }^{100}$ Department of Finance memorandum for the government on land division policy, 28 Nov. 1948 (ibid.).

${ }^{101}$ Ibid.

${ }^{102}$ Ibid.
} 
well over half a century, readers will search in vain in all the standard textbooks for anything more than the most cursory reference to it. ${ }^{103}$

The type of agrarian violence that had characterised pre-independence Ireland may have dissipated after 1923; however, social unrest was never far below the surface as rural society remained in a state of continual flux where some people lived with the hope that the government, through the working of the Land Commission, would improve their social and economic situation by giving them more land, while others lived with the fear and the insecurity that the commission might compulsorily acquire their land. Thus the continued hunger for land in independent Ireland, allied to the impact of land acquisition and division on so many people, ensured that the land reform question remained one of the most potent political issues at both local and national level right up to the early $1980 \mathrm{~s}$. Very often it led to political success or determined political demise.

While the merging of the land question with the national question in the nineteenth century guaranteed the former a pivotal position in Irish historiography up to independence, it remarkably has not featured in the historiography of the post-independence era. In the light of the evidence presented here, it would make for an interesting study to examine how this came to be, although, as stated in the introduction, one suspects that the anomalous position of the Irish Land Commission records and the difficulty in gaining access to these is to a large degree responsible. ${ }^{104}$

TERENCE DOOLEY Department of History, National University of Ireland, Maynooth

${ }^{103}$ See above, pp 175-6 and n. 3 .

${ }^{104}$ I should like to express my gratitude to the National University of Ireland for allowing me the opportunity as Postdoctoral Fellow in the Humanities to carry out the research on which this article is based. 